\title{
Hubungan Antara Kepuasan Kerja DenganKinerja Penyuluh Pertanian Di BP3K Kabupaten Tanjung Jabung Barat
}

\begin{abstract}
Relationship Between Job Satisfaction With Performance Agricultural Extension In BP3K
\end{abstract} Tanjung Jabung Barat

\author{
Satriadi $^{1),}$ Arsyad Lubis ${ }^{2)}$ dan Aprollita ${ }^{2)}$ \\ $\left.{ }^{1}\right)$, Alumni Jurusan Agribisnis Program Studi Penyuluh danPengembangan Masyarakat Agribisnis \\ Fakultas Pertanian UNJA \\ ${ }^{2)}$ Staf Pengajar Jurusan Agribisnis Fakultas Pertanian Unja \\ Email: Satriady@facebook.com
}

\begin{abstract}
ABSTRAK
Penelitian ini bertujuan untuk mengetahui kepuasan kerja penyuluh pertanian, mengetahui kinerja penyuluh pertanian, dan mengetahui hubungan antara kepuasan kerja dengan kinerja penyuluh pertanian di Kabupaten Tanjung Jabung Barat. Penentuan lokasi penelitian dilakukan secara sengaja (purposive) dengan berdasarkan pertimbangan-pertimbangan tertentu yang disesuaiakan dengan tujuan penelitian. Penelitian ini sudah dilakukan pada tanggal 17 maret sampai dengan 18 april 2016. Pengambilan sampel dilakukan dengan menggunakan metode sensus yaitu dengan mengambil semua responden berdasarkan kecamatan yang mempunyai produktivitas tertinggi. Kecamatan yang mempunyai produktivitas padi tertinggi yaitu Kecamatan Batang Asam dan Kecamatan Seyerang, sehingga total sampel sebanyak 12 orang. Data yang digunakan dalam penelitian ini adalah data primer dan sekunder sedangkan teknik pengumpulan data dengan wawancara, observasi dan pencatatan. Untuk mengetahui tingkat kepuasan kerja penyuluh pertanian diukur dengan menggunakan Skala Likert, sedangkan kinerja penyuluh diukur dengan mengikuti ketetapan dari permentan (2013) dan untuk mengetahui derajat hubungan antara kepuasan kerja dan kinerja penyuluh pertanian digunakan uji korelasi Rank Sperman $\left(r_{s}\right)$. Hasil penelitian menunjukan Tingkat kepuasan kerja penyuluh di Kabupaten Tanjung Jabung Barat sebagian besar berada pada kategori sedang, sedangkan Tingkat kinerja penyuluh pertanian di Kabupaten Tanjung Jabung Barat sebagian besar berada pada tingkat cukup dan Hubungan antara kepuasan kerja dengan kinerja penyuluh pertanian di Kabupaten Tanjung Jabung Barat pada tingkat kepercayaan 95 persen terdapat hubungan yang positif dan signifikan antara kepuasan kerja dengan kinerja penyuluh.
\end{abstract}

Kata kunci : Penyuluh, Kepuasan Kerja dan Kinerja Penyuluh Pertanian

\section{ABSTRACT}

This study aims to determine job satisfaction agricultural extension, determine the performance of agricultural extension, and determine the relationship between job satisfaction and performance of agricultural extension in Tanjung Jabung Barat. Location research done intentionally ( purposive ) on the basis of certain considerations which coinciding with the purpose of research. This research has been conducted on 17 March to 18 April 2016. Sampling was done by census method is by taking all respondents by districts that have the highest productivity. Sampling was done by census method is by taking all respondents by districts that have the highest productivity. Districts that have the highest productivity of rice and District District of Batang Asam Seyerang, so the total sample of 12 people. The data used in this study are primary and secondary data, while data collecting technique through interview, observation and recording. To determine the level of job satisfaction agricultural extension was measured using the Likert Scale, while the educator's performance is measured by following the provisions of Permentan (2013) and to determine the degree of correlation between job satisfaction and performance of agricultural extension used Spearman rank correlation test ( $r s$ ). The results showed level of job satisfaction extension in Tanjung Jabung Barat mostly in the category of medium, while the rate of performance of agricultural extension in West Tanjung Jabung mostly located at sufficient levels and relationship between job satisfaction and performance of agricultural 
extension in Tanjung Jabung Barat, on 95 percent confidence level there is a positive and significant relationship between job satisfaction and performance extension.

Keywords : Extension, Job Satisfaction and Performance Agricultural Extension

\section{PENDAHULUAN}

Pembangunan pertanian adalah proses untuk meningkatkan kualitas hidup masyarakat tani. Di Indonesia pembangunan pertanian merupakan bagian terpenting dari pembangunan nasional karena sebagian besar penduduk Indonesia menggantungkan kehidupannya dari sektor pertanian. Untuk itu diperlukan sumberdaya manusia yang berkualitas didalam pembangunan pertanian.

Pembangunan sumber daya manusia pertanian, termasuk pembangunan kelembagaan penyuluhan dan peningkatan kegiatan penyuluh pertanian, merupakan faktor yang memberikan kontribusi besar terhadap keberhasilan pembangunan pertanian di Indonesia. Dalam rangka meningkatkan kontribusi sektor pertanian terhadap pembangunan nasional Kementrian Pertanian telah menetapkan 4 (empat) sukses pembangunan pertanian, yaitu : (1) pencapaian swasembada dan swasembada berkelanjutan, (2) peningkatan diversifikasi pangan, (3) peningkatan nilai tambah, daya saing dan ekspor, dan (4) peningkatan kesejahteraan petani. Untuk mewujudkan 4 (empat) sukses pembangunan pertanian tersebut, diperlukan sumber daya manusia yang berkualitas, handal, serta berkemampuan menejerial, kewirausahaan dan organisasi bisnis sehingga pelaku pembangunan pertanian mampu membangun usaha dari hulu sampai dengan hilir yang berdaya saing tinggi dan mampu menerapkan prinsip pembangunan pertanian berkelanjutan sebagaimana yang tertulis dalam Peraturan Menteri Pertanian tahun 2013.

Dalam rangka meningkatkan peran sektor pertanian khususnya tanaman pangan dalam program pembangunan nasional, petani sebagai pelaku utama dituntut untuk mengembangkan usahatani yang produktif, menguntungkan dan mandiri, oleh karena itu diperlukan petani yang berkualitas, andal dan serta berkemampuan manajerial, kewirausahaan dan organisasi bisnis. Petani diharapkan mampu membangun usahatani yang berdaya saing tinggi, dan mampu berperan dalam melestarikan lingkungan hidup sejalan dengan prinsip pembangunan berkelanjutan.

Berdasarkan data BPS Propinsi Jambi tahun 2015, Kabupaten Tanjung Jabung Barat masih tergolong rendah dalam hal produktivitas $(38.95 \mathrm{Kw} / \mathrm{Ha})$ dibandingkan produktivitas padi di Kabupaten Kerinci (Tertinggi di Provinsi Jambi yaitu $56.39 \mathrm{Kw} / \mathrm{Ha}$ ). Rendahnya produktivitas usaha tani padi di Kabupaten Tanjung Jabung Barat diperkirakan berhubungan erat dengan peran aktifnya penyuluh dalam membentuk petani berkualitas, andal dan serta berkemampuan manajerial, kewirausahaan dan organisasi bisnis.

Penyuluhan pada hakekatnya merupakan suatu kegiatan pendidikan non formal dalam rangka mengubah masyarakat menuju keadaan yang lebih baik seperti yang dicita-citakan. Dalam upaya mengubah masyarakat tersebut terdapat unsur-unsur seperti gagasan yang didikan, pihak yang memprakarsai perubahan masyarakat secara keseluruhan, tenaga penyebar gagasan yang dimaksud, anggota masyarakat baik secara individu maupun secara keseluruhan yang menjadi sasaran dari kegiatan penyuluhan tersebut ( Nasution, 1990).

Penyuluh pertanian sebagai ujung tombak pembangunan pertanian diharapkan dapat mengarahkan pembangunan pertanian di lapangan dengan mendorong pelaku utama pembangunan pertanian (petani dan pelaku usaha pertanian lainnya) untuk meningkatkan pendapatan dan kesejahteraan keluarganya. Penyuluh pertanian adalah pegawai negeri sipil yang (PNS) yang diberi tugas, tanggung jawab, wewenang dan hak secara penuh oleh pejabat yang berwenang oleh satuan organisasi lingkup pertanian untuk melakukan kegiatan penyuluhan (Permentan, 2013).

Kabupaten Tanjung Jabung Barat terdiri atas 13 Kecamatan dan 134 Desa/Kelurahan. Kabupaten Tanjung Jabung Barat memiliki PPL yang tersebar di BP3K Kecamatan Tanjung Jabung Barat. Penyuluh PNS terbanyak berada di Kecamatan Betara yaitu 13 penyuluh dan penyuluh PNS yan sedikit berada di Kecamatan Tebing Tinggi yang berjumlah 3 penyuluh.

Peran penyuluh dalam pemberdayaan pertani di Kabupaten Tanjung Jabung Barat yaitu berupa penyuluhan-penyuluhan dan pelatihan-pelatihan tentang peningkatan teknologi, sikap dan keterampilan petani. Sehingga pertani itu mempunyai keinginan untuk dapat meningkatkan taraf hidup yang lebih baik. Berdasarkan data BPS (Badan Pusat Statistik) Provinsi Jambi 2015 menunjukan bahwa produktivitas tertinggi berada di Kecamatan Batang Asam yaitu $41.93 \mathrm{KW} / \mathrm{Ha}$, kemudian diikuti oleh Kecamatan Senyerang 39.76 $\mathrm{KW} / \mathrm{Ha}$. Sedangkan produktivitas terendah berada di kecamatan Tungkal Ulu dengan produktifitas 37,55 
$\mathrm{KW} / \mathrm{Ha}$, disusul dengan Kecamatan Betara dan Kecamatan Kuala Betara dengan produktivitas 38.10 KW/Ha. Kecamatan Batang Asam berada pada posisi pertama dalam produktifitas disusul dengan senyerang. Dengan demikian dapat disimpulkan bahwa penerapan teknologi padi sawah di Kecamatan Batang Asam dan Kecamatan Senyerang relatif lebih unggul jika dibandingkan dengan Kecamatan lainya di Kabupaten Tanjung Jabung Barat.

Tinggi rendahnya produktifitas padi di Kecamatan yang ada di Kabupaten Tanjung Jabung Barat, tentunya tidak lepas dari peran aktif tidaknya penyuluh dalam melaksanakan tugasnya. Hal ini membuktikan bahwa kinerja penyuluh harus diperhatikan yang dengan baik. Banyak faktor yang dapat mempengaruhi kinerja penyuluh, salah satunya adalah kepuasan kerja.

Kepuasan kerja merupakan salah satu faktor yang sangat penting untuk mendapatkan hasil kerja yang optimal. Ketika seorang merasakan kepuasan dalam bekerja tentunya ia akan berupaya semaksimal mungkin dengan segenap kemampuan yang dimilikinya untuk menyelesaikan tugas pekerjaannya. Dengan demikian produktivitas dan hasil kerja pegawai akan meningkat secara optimal.

Dalam kenyataannya, di Kabupaten Tanjung Jabung Barat kepuasan kerja secara menyeluruh belum mencapai tingkat maksimal. Dalam menjalankan tupoksinya, penyuluh langsung turun kelapangan menemui para petani namun terkadang penyuluh kesulitan untuk melayani petani yang agak berjauhan dan juga diberbagai tempat medan yang dilalui penyuluh sangatlah sulit dikarenakan jalan belum sepenuhnya baik ditambah lagi dengan terbatasnya biaya operasional penyuluh menjadi kendala penyuluh dalam menjalankan kegiatan penyuluhan.

Penyuluh pertanian tidak dapat melepaskan diri dari kenyataan bahwa mereka adalah individu yang juga mempunyai kebutuhan, keinginan dan harapan dari tempat bekerjanya. Hal ini berkaitan erat dengan kualitas hasil kerja penyuluh pertanian itu sendiri yang sesungguhnya dipengaruhi oleh kepuasan kerja masing-masing individu.

Sangat disadari bahwa, sebagai profesi yang bertugas memberikan informasi, membimbing, memandu dan memberi contoh kepada para petani di pedesaan, maka para penyuluh pertanian itu sendiri semestinya memiliki kepuasan kerja yang baik agar melalui kinerjanya dapat memberikan produktivitas dan manfaat yang sebesar-besarnya bagi yang membutuhkan yakni para petani di pedesaan.

Karena kepuasan adalah sikap emosional yang menyenangkan dan mencintai pekerjaannya. (Hasibuan, 2001). Jadi apabila penyuluh tidak mendapatkan kepuasan kerjanya, Maka akan berpengaruh terhadap kinerjanya dalam mendidik memotivasi membina petani. Hal ini akan menyebabkan penurunan hasil produksi pertanian yang ada di Kabupaten Tanjung Jabung Barat, karena kita ketahui penyuluh merupakan tulang punggung dalam peningkatan produksi hasil pertanian. Sehingga perlu dilakukan penelitian terhadap kepuasan kerja dan hubungannya terhadap kinerja penyuluh.

\section{METODE PENELITIAN}

Penelitian ini dilaksanakan di BP3K (Balai Penyuluhan Pertanian Perikanan dan Kehutanan) Kecamatan Batang Asam, dan di BP3K Kecamatan Senyerang Kabupaten Tanjung Jabung Barat. Lokasi ini dipilih secara sengaja (purposive) atas pertimbangan, bahwa dikedua BP3K Kecamatan ini diduga kegiatan penyuluhan aktif karna memiliki produktivitas padi tertinggi dibandingkan dengan Kecamatan lain di Kabupaten Tanjung Jabung Barat.

Penelitian ini dilakukan untuk mengetahui hubungan kepuasan kerja dengan kinerja penyuluh pertanian di Kabupaten Tanjung Jabung Barat, sehingga dapat diketahui hubungan kepuasan kerja dengan kinerja penyuluh pertanian di Kabupaten Tanjung Jabung Barat. penelitian ini dilaksanakan dari tanggal 17 maret 2016 sampai dengan 18 april 2016

Dalam penelitian ini digunakan dua jenis data yaitu data primer dan data sekunder. Pengumpulan data primer dilakukan dengan metode sensus yaitu dengan cara melakukan wawancara dan observasi langsung kepada seluruh penyuluh pertanian di BP3K Kecamatan Batang Asam dan BP3K Senyerang yang berjumlah 12 Orang, dengan menggunakan angket atau kuisioner yang telah di sediakan.Data sekunder merupakan data yang diperoleh melalui lembaga atau instansi terkait dan berbagai literatur yang berkaitan dengan topik penelitian. Data sekunder juga digunakan sebagai kelengkapan data penelitian 
Metode pengumpulan data primer dilakukan melalui wawancara dan observasi. Wawancara dilakukan dengan cara mengajukan pertanyaan kepada responden berdasarkan kuisioner sehingga akan diperoleh informasi yang berhubungan dengan persoalan yang diteliti. Responden dalam penelitian ini adalah seluruh Penyuluh yang ada di BP3K Kecamatan Batang Asam dan BP3K Senyerang. Kuisioner merupakan alat pengumpulan data berupa daftar pertanyaan yang berkaitan dengan Persoalan yang diteliti. Disamping itu dilakukan observasi melalui pengamatan langsung dilapangan. Sedangkan data sekunder dikumpulkan dengan cara mencari, membaca, menelusuri, dan mengutip berbagai literatur yang berkaitan dengan permasalahan yang diteliti.

Kabupaten Tanjung Jabung Barat memiliki 13 BP3K yang meliputi 13 Kecamatan. Dari 13 BP3K tersebut dipilih 2 BP3K, Penentuan lokasi penelitian dilakukan secara sengaja (purposive) dengan pertimbanganpertimbangan yang disesuaiakan dengan tujuan penelitian (Singarimbun, 1995). Lokasi yang dipilih dalam penelitian yaitu BP3K Batang Asam dan BP3K Senyerang, karna memiliki produktivitas padi tertinggi dibandingkan Kecamatan lain di Kabupaten Tanjung Jabung Barat

Populasi penyuluh pertanian di BP3K Batang Asam dan BP3K Senyerang Kabupaten Tanjung Jabung Barat berjumlah 12 Orang penyuluh PNS (Tabel 1). Metode yang digunakan adalah metode sensus sehingga seluruh penyuluh PNS yang ada di BP3K Kecamatan Batang Asam dan BP3K Senyerang yang berjumlah 12 Orang penyuluh PNS dijadikan sebagai sampel.

Untuk mengetahui tingkat kepuasan kerja dan tingkat kinerja penyuluh pertanian dalam penelitian ini dilakukan secara deskriptif dengan menggunakan tabulasi melalui persentase dan skoring. Rumus yang digunakan dalam perhitungan data adalah rumus yang sesuai dengan judul penelitian yang menyatakan hubungan (asosiatif), perbandingan 2 variabel (komparatif) dan jenis data adalah berjenjang (Ordinal). Menurut Djarwanto (1995) untuk melihat nilai $r_{s}$ (koefisien korelasi Spearman) dihitung dengan rumus :

$\mathrm{r}_{\mathrm{s}}=1-\frac{6 \sum d i^{2}}{\mathrm{n}\left(\mathrm{n}^{2}-1\right)}$

Untuk mengetahui apakah koefisien ini signifikan atau tidak maka perlu dibandingkan dengan tabel nilai $\rho_{\mathrm{s}}$ pada $\alpha=0,05 ; d b=N(12)$ adalah 0,497

Kaidah pengambilan keputusan adalah sebagai berikut :

1. Terima Ho apabila $r_{s} \leq$ tabel nilai $\rho_{s} ; d b=N(a=0,05)$

2. Tolak Ho apabila $r_{s}>$ tabel nilai $\rho_{s} ; d b=N(a=0,05)$

Keterangan :

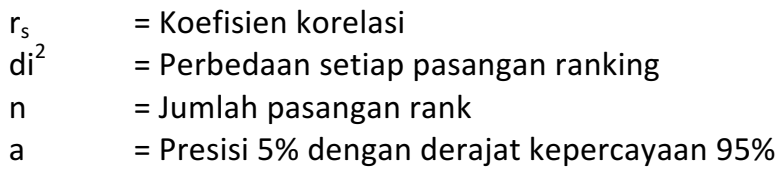

\section{Identitas Responden}

\section{HASIL DAN PEMBAHASAN}

\section{Umur Responden}

Umur seseorang berkaitan erat dengan tingkat perkembanganya. Secara kronologi, umur memberi pertunjuk tentang tingkat perkembangan individu. (Salkind, 1985). Umur adalah satu identitas yang dapat mempengaruhi pola pikir seseorang. Semakin tua umur seseorang maka semakin matang cara berfikirnya untuk mengatasi masalahnya, serta semakin banyak pengalaman dan pendidikan yang dapat diperoleh. Umur memegang peranan penting dalam menyampaikan inovasi kepada petani, hal ini disebabkan umur akan mempengaruhi ketahanan fisik dan kemampuan penyuluh dalam bekerja serta mempengaruhi penyuluh dalam berfikir dan mengambil keputusan. Penyuluh muda memiliki kemampuan fisik relatif kuat dibandingkan dengan kemampuan fisik penyuluh yang lebih tua, namun biasanya penyuluh yang lebih tua akan berhati-hati dalam menyampaikan informasi kepada petani. Hasil penelitian memperlihatkan bahwa umur penyuluh yang bertugas dalam lingkup BP3K di Kabupaten Tanjung Jabung Barat berkisar antar 33- 50 tahun. Untuk lebih jelasnya 
ISSN: 1412-8241 (p); 2621-1246 (e), Volume 21. no (1) 2018

DOI: 10.22437 jiseb.v21i1

mengenai penyebaran penyuluh PNS berdasarkan kelompok umur di daerah penelitian dapat dilihat pada Tabel 1 berikut ini.

Tabel 1. Distribusi, Frekuensi dan Persentase PPL Responden Berdasarkan Kelompok Umur di Daerah Penelitian

\begin{tabular}{cccc}
\hline No & Umur PPL (tahun) & Frekuensi (Orang) & Persentase (\%) \\
\hline 1 & $33-38$ & 3 & 25 \\
2 & $39-44$ & - & - \\
3 & $45-50$ & 3 & 25 \\
4 & $51-56$ & 6 & 50 \\
\hline
\end{tabular}

Tabel 1 di atas memperlihatkan bahwa, persentase umur terbesar penyuluh pertanian di daerah penelitian berada pada kelas umur 51- 56 tahun yaitu sebesar 50\%, bila dikaji berdasarkan karakteristik umur produktif penyuluh pertanian sampai dengan 60 tahun (badan pengembangan sumberdaya manusia pertanian 2007), maka semua penyuluh pertanian di daerah penelitian memiliki usia produktif sehingga mempengaruhi kinerja penyuluh. Umur terkait dengan peranan dan perilaku seseorang, umur juga akan mempengaruhi kemampuan kerja seseorang. Sedangkan kemampuan kerja juga terkait erat dengan produktivitas kerja seseorang (Sulistiyani dan Rosidah, 2003).

\section{Tingkat Pendidikan Formal Responden}

Salah satu faktor yang dapat berpengaruh terhadap kemampuan dan pengetauhan seseorang adalah faktor pendidikan. Pendidikan merupakan aktivitas dan usaha manusia untuk meningkatkan kepribadiannya dengan jalan membina potensi-potensi pribadinya yaitu daya pikir, karsa, rasa, cipta dan budi nurani (Ihsan Fuad, 2005). Semakin tinggi tingkat pendidikan maka akan semakin luas wawasan, pengetauhan serta pola pikir penyuluh. Untuk lebih jelasnya tingkat pendidikan formal penyuluh di daerah penelitian dapat dilihat pada Tabel 2 berikut ini.

Tabel 2. Distribusi, Frekuensi dan Persentase PPL Responden Berdasarkan Tingkat Pendidikan Formal di Daerah Penelitian Tahun 2016.

\begin{tabular}{cccc}
\hline No & Tingkat pendidikan & Frekuensi (Orang) & Persentase (\%) \\
\hline 1 & SPP-SPMA Sederajat & 4 & 33.3 \\
2 & DIII & - & - \\
3 & S1 & 8 & 66.7 \\
\hline
\end{tabular}

Tabel 2 di atas memperlihatkan sebagian besar penyuluh pertanian berpendidikan S1 yaitu sebanyak 8 orang penyuluh pertanian $(66.7 \%)$. Dari data tersebut dapat dikatakan bahwa tingkat pendidikan penyuluh pertanian di daerah penelitian relative tinggi. Tingginya tingkat pendidikan penyuluh berpengaruh dalam menjalankan tugasnya.

\section{Lama Bekerja Responden}

Masa kerja merupakan salah satu faktor yang berperan penting dalam hal tingkat pengambilan keputusan. Menurut Siagian (2003) menyatakan bahwa masa kerja merupakan keseluruhan pelajaran yang dipetik oleh seseorang dari peristiwa-peristiwa yang dilalui dalam perjalanan hidupnya. Pengalaman Pengalaman bekerja penyuluh responden dapat diukur dalam tahun sejak penyuluh pertama kali bekerja. Dari hasil penelitian diketauhi bahwa pengalaman bekerja penyuluh pertanian menyebar dari $1-34$ tahun. Untuk lebih jelasnya pengalaman bekerja atau lama bekerja penyuluh pertanian dapat dilihat pada Tabel 3 berikut ini.

Tabel 3. Distribusi, Frekuensi dan Persentase PPL Responden Berdasarkan Lama Berkerja di Daerah Penelitian Tahun 2016.

\begin{tabular}{cccc}
\hline No & Lama Berkerja (tahun) & Frekuensi (Orang) & Persentase (\%) \\
\hline 1 & $1-8$ & 3 & 25 \\
2 & $9-17$ & - & - \\
\hline
\end{tabular}




\begin{tabular}{cccc}
\hline 3 & $18-26$ & 4 & 33.3 \\
4 & $27-36$ & 5 & 41.7 \\
\hline & Jumlah & 12 & 100 \\
\hline
\end{tabular}

Tabel 3. diatas memperlihatkan bahwa pengalaman bekerja penyuluh pertanian terbesar di daerah penelitian berkisar antara $27-36$ tahun berjumlah 5 orang (41,7\%). Keadaan PPL di daerah penelitian ini dapat dikatakan cukup berpengalaman dalam menyampaikan informasi baru kepada petani.

\section{Kepuasan Kerja}

Kepuasan kerja adalah Sikap emosional yang menyenangkan dan mencintai pekerjaanya, Malayu S.P Hasibuan (2008). Oleh karena itu pemenuhan kebutuhan, perasaan tentang pengakuan, dan kondisi kerja penyuluh menjadi perhatian utama. Dalam penilaiannya, tingkat kepuasan kerja penyuluh pertanian di Kabupaten Tanjung Jabung Barat dikategorikan dalam lima tingkatan yaitu Sangat Tinggi, Tinggi, Sedang, Rendah, Sangat Rendah. Kepuasan kerja penyuluh secara rinci dapat dilihat pada Tabel 8 berikut ini.

Tabel 11. Distribusi Frekuensi Responden Berdasarkan Kepuasan Kerja Penyuluh Pertanian di Daerah Penelitian Tahun 2016.

\begin{tabular}{clcc}
\hline No. & \multicolumn{1}{c}{ Kategori tingkat } & Frekuensi (Orang) & Persentase (\%) \\
\hline 1 & Sangat Tinggi & 0 & 0 \\
2 & Tinggi & 1 & 8.33 \\
3 & Sedang & 6 & 50 \\
4 & Rendah & 5 & 41.67 \\
5 & Sangat Rendah & 0 & 0 \\
\hline Jumlah & & 12 & 100 \\
\hline
\end{tabular}

Berdasarkan tabel 8 diatas dapat diketahui bahwa jumlah penyuluh berdasarkan tingkat kepuasan kerja untuk kategori sedang sejumlah 6 responden atau 50 \%. Dengan demikian dapat dikatakan bahwa kepuasan kerja penyuluh pertanian di daerah penelitian sebagian besarnya berada pada kategori sedang. Secara rinci kepuasan kerja penyuluh dari masing-masing aspek kepuasan kerja adalah sebagai bebagai berikut :

\section{Kebutuhan}

Kebutuhan penyuluh merupakan suatu imbalan yang diterima oleh penyuluh sebagi hasil kerjanya. Kebutuhan adalah aspek yang mempengaruhi kepuasan kerja penyuluh. Aspek kebutuhan meliputi gaji, tunjangan dan promosi. Dimensi kepuasan kerja dari aspek kebutuhan kerja dapat dilihat pada Tabel 12 berikut ini.

Tabel 12. Dimensi Kepuasan Kerja Pada Aspek Kebutuhan Penyuluh Di Daerah Penelitian Tahun 2016.

\begin{tabular}{clcc}
\hline No. & \multicolumn{1}{c}{ Kategori Tingkat } & Frekuensi (Orang) & Persentase (\%) \\
\hline 1 & Sangat Tinggi & 0 & 0 \\
2 & Tinggi & 0 & 0 \\
3 & Sedang & 6 & 50 \\
4 & Rendah & 6 & 50 \\
5 & Sangat Rendah & 0 & 0 \\
\hline Jumlah & & $\mathbf{1 2}$ & $\mathbf{1 0 0}$ \\
\hline
\end{tabular}

Tabel 12 memperlihatkan bahwa tidak ditemukan penyuluh yang pada kategori sangat tinggi, tinggi dan sangat rendah, Sebagian besar (50 \%) penyuluh pada kategori sedang dan rendah dari aspek kebutuhan. Dengan demikian dapat ditarik kesimpulan bahwa kepuasan kerja pada aspek kebutuhan penyuluh pertanian didaerah penelitian sebagian besar tergolong pada kategori diantara sedang dan rendah.

Berdasarkan dengan penelitian di lapangan sebagian besar penyuluh berpendapat netral dengan gaji yang diterima cukup untuk memenuhi kebutuhan keluarganya. akan tetapi penyuluh tidak setuju pada aspek kebutuhan lain karena penyuluh merasa jumlah tunjangan yang diterima belum dapat memenuhi kebutuhan dalam melaksanakan tugas penyuluhan. Pengertian kepuasan kerja adalah suatu penilaian dari seseorang mengenai seberapa jauh pekerjaannya secara keseluruhan mampu memuaskan kebutuhannya, dapat dikatakan 
pula bahwa kepuasan kerja merupakan perasaan pekerja terhadap pekerjaannya (Asa'ad, 1995). Dengan demikin kebutuhan adalah aspek yang sangat mempengaruhi terhadap kepuasan kerja, karna setiap orang bekerja pasti mengharakan kebutuhan yang meliputi gaji, tunjangan, dan promosi.

\section{Perasaan}

Kepuasan kerja adalah seperangkat perasaan penyuluh tentang hal menyenangkan atau tidak menyenangkan pekerjaan yang dilakukan, baik didasarkan atas imbalan material maupun psikologis. Perasaan tentang pengakuan merupakan suatu penghormatan yang diberikan pemerintah berupa sertifikat yang sah yang akan diberikan bila mana orang telah mencapai suatu prestasi kerja dalam pekerjaanya. Aspek perasaan tentang pengakuan meliputi perasaan tentang pengakuan atas prestasi, penghargaan dan rasa keadilan. Di daerah penelitian, penyuluh mempunyai persepsi yang berbeda terhadap perasaan akan pengakuan, dimensi kepuasan kerja pada aspek perasaan akan pengakuan dapat dilihat pada Tabel 13 sebagai berikut:

Tabel 13. Dimensi Kepuasan Kerja Pada Aspek Perasaan Penyuluh Di Daerah Penelitian Tahun 2016.

\begin{tabular}{clcc}
\hline No & \multicolumn{1}{c}{ Kategori Tingkat } & Frekuensi (Orang) & Persentase (\%) \\
\hline 1 & Sangat Tinggi & 0 & 0 \\
2 & Tinggi & 1 & 8.33 \\
3 & Sedang & 4 & 33.33 \\
4 & Rendah & 7 & 58.33 \\
5 & Sangat Rendah & 0 & 0 \\
\hline Jumlah & & $\mathbf{1 2}$ & $\mathbf{9 9}$ \\
\hline
\end{tabular}

Berdasarkan Tabel 10 memperlihatkan bahwa tidak ditemukannya penyuluh yang pada kategori sangat tinggi dan sangat rendah pada aspek perasaan tentang pengakuan. Sebagian besar penyuluh (58.33 persen) berada pada tingkat kategori rendah pada aspek perasaan tentang pengakuan. Dengan demikian dapat ditarik kesimpulan bahwa kepuasan kerja pada aspek perasaan tentang pengakuan penyuluh pertanian didaerah penelitian sebagian besar tergolong pada kategori rendah.

Berdasarkan dengan penelitian dilapangan rendahnyakepuasan penyuluh pada aspek perasaan akan pengakuan, dikarenakan tolak ukur penyuluh dengan membandingkan akan rasa keadilan yang dirasakan kepada BP3K lain. penyuluh di daerah penelitian tergolong dalam penyuluh yang sudah lama bekerja bahkan sebagian besar sudah memasuki masa pensiun, maka dari itu biasanya pada tingkat yang demikian biasanya penyuluh menuntut lebih akan pengakuan, prestasi dan penghargaan atas pengapdiannya selama ini.

\section{Kondisi Kerja}

Kondisi kerja yang nyaman akan berpengaruh pada tingkat penyampaian informasi serta komunikasi penyuluh. Penyuluh membutuhkan kondisi kerja yang nyaman untuk melakukan aktivitas keseharianya. Kondisi kerja meliputi isi pekerjaan, lingkungan fisik, lingkungan sosial dan pendelegasian. Berdasarkan hasil penelitian, data yang dipeloleh dari responden dapat dilihat pada Tabel 11. Berikut:

Tabel 14. Dimensi Kepuasan Kerja Pada Aspek Kondisi Kerja Penyuluh Di Daerah Penelitian Tahun 2016.

\begin{tabular}{rlcc}
\hline No. & \multicolumn{1}{c}{ Kategori Tingkat } & Frekuensi (Orang) & Persentase (\%) \\
\hline 1 & Sangat Tinggi & 0 & 0 \\
2 & Tinggi & 0 & 0 \\
3 & Sedang & 8 & 66.67 \\
4 & Rendah & 4 & 33.33 \\
5 & Sangat Rendah & 0 & 0 \\
\hline Jumlah & & $\mathbf{1 2}$ & $\mathbf{1 0 0}$ \\
\hline
\end{tabular}

Berdasarkan Tabel 11 memperlihatkan bahwa tidak ditemukannya penyuluh pada tingkat kategori sangat tinggi, tinggi dan sangat rendah pada aspek perasaan tentang pengakuan. Sebagian besar penyuluh 
(66.67persen) berada pada kategori sedang pada aspek kondisi kerja. Dengan demikian dapat ditarik kesimpulan bahwa kepuasan kerja pada aspek kondisi kerja pertanian didaerah penelitian sebagian besar tergolong pada kategori sedang.

Berdasarkan penelitian dilapangan sebagian besar penyuluh mengungkapkan bahwa pengaturan waktu kerja dan waktu istirahat telah sesuai dengan pekerjaan yang harus dilaksanakan, semua penyuluh responden menyatakan bahwa netral dengan pengaturan waktu kerja dan waktu istirahat sudah sesuai. Demikian juga dengan wewenang dan danggung jawab yang diberikan atasan telah sesuai dengan tugas penyuluh. Terkait dengan perlengkapan kerja dan kondisi ruang kerja sebagian besar penyuluh mengungkapkan setuju dengan perlengkapan kerja dan kondisi ruang kerja yang ada, kondisi ruang kerja dirasakan sudah cukup bersih dan tata ruangnya cukup menyenangkan.

Kondisi ini disebabkan karena sebagian besar penyuluh pertanian yang ada di daerah penelitian sudah berpengalaman, mereka sudah betah dan terbiasa dengan kondisi kerja baik di kantor maupun dilingkungan kerjanya dan juga mereka sudah paham betul dengan wewenangnya dan tangung jawabnya. Penyuluh pertanian kebanyakan bertempat tinggal di daerah wilayah binaanya, sehingga memudahkan mereka dalam penyampaian informasi kepada petani. Sedangkan di BP3K Kecamatan Batang Asam terdapat penyuluh yang tidak tinggal di wilayah binaan akan tetapi akses jalan yang bagus memudahkan penyuluh dalam menyampaikan informasi kepada petani.

\section{Kinerja Penyuluh}

Rahmanto (1997) menyebutkan kinerja atau prestasi kerja sebagai tingkat pelaksanaan tugas yang bisa dicapai oleh seseorang, unit atau divisi dengan menggunakan kemampuan yang ada dan batasan-batasan yang telah ditetapkan untuk mencapai tujuan perusahaan. Sehingga kinerja dikatakan baik dan sukses jika tujuan yang diinginkan dapat tercapai dengan baik. Dalam penilaian kinerja penyuluh pertanian mengikuti cara yang sudah ditetapkan oleh permentan 2013, dikategorikan dalam lima tingkatan yaitu sangat baik, baik, cukup, kurang baik dan buruk. Adapun secara rinci dapat dilihat dalam Tabel 8 sebagai berikut:

Tabel 8. Tingkat Kinerja Penyuluh Pertanian di Kabupaten Tanjung Jabung Barat

\begin{tabular}{cccc}
\hline No. & Kategori Tingkat & Frekuensi (Orang) & Persentase (\%) \\
\hline 1 & Sangat Baik & - & - \\
2 & Baik & 1 & 8.3 \\
3 & Cukup & 8 & 66.7 \\
4 & Kurang Baik & 3 & 25 \\
5 & Buruk & - & - \\
\hline Jumlah & & $\mathbf{1 2}$ & $\mathbf{1 0 0}$ \\
\hline
\end{tabular}

Berdasarkan Tabel 8. Memperlihatkan bahwa tidak ditemukanya penyuluh yang kinerjanya sangat baik maupun buruk. sebagian besar yaitu 8 orang penyuluh ( 66.7 persen) berdasarkan kinerjanya termasuk dalam kategori cukup. Dengan demikian dapat ditarik kesimpulan bahwa kinerja penyuluh pertanian di Kabupaten Tanjung Jabung Barat tergolong pada kategori cukup.

Kinerja penyuluh pertanian di Kabupaten Tanjung Jabung Barat diketahui dengan jumlah angka kredit dari masing-masing kegiatan penyuluh. Dalam hal ini adalah persiapan penyuluhan pertanian, pelaksanaan penyuluhan pertanian, evaluasi dan pelaporan(Permentan, 2013). Secara rinci kinerja dari penyuluh terhadap masing-masing aspek kinerja adalah sebagai bebagai berikut:

\section{Persiapan Penyuluh Pertanian}

Kegiatan persiapan penyuluhan pertanian adalah kegiatan yang dilakukan oleh penyuluh sebelum melaksanakan kegiatan penyuluhan pertanian yang meliputi Membuat data potensi wilayah, Memandu (pengawalan dan pendampingan) penyusunan RDKK, Penyusunan programa penyuluhan pertanian Desa dan Kecamatan dan Membuat Rencana Kerja Tahunan Penyuluh Pertanian (RKTPP). Berdasarkan analisis di lapang tentang kinerja penyuluh pada aspek persiapan penyuluh pertanian di daerah penelitian secara rinci dapat dilihat dalam Tabel 9 sebagai berikut : 
ISSN: $1412-8241$ (p); 2621-1246 (e), Volume 21. no (1) 2018

DOI: $10.22437 / j i s e b . v 21 i 1$

Tabel 9. Dimensi Kinerja Penyuluh Pada Aspek Persiapan Penyuluh Pertanian Di Daerah Penelitian Tahun 2016.

\begin{tabular}{clccccc}
\hline \multirow{2}{*}{ No } & \multirow{2}{*}{ Indikator } & \multicolumn{4}{c}{ Skor Jarak } \\
\cline { 3 - 7 } & & SB & Ba & C & TB & Bu \\
\hline 1 & Membuat data Potensi wilayah & 11 & 1 & 0 & 0 & 0 \\
2 & Memandu penyusunan RDKK & 10 & 1 & 0 & 1 & 0 \\
3 & Penyusunan programa & 7 & 4 & 1 & 0 & 0 \\
4 & Membuat rencana kerja tahunan & 10 & 2 & 0 & 0 & 0 \\
\hline Rata-rata & $\mathbf{9 . 5}$ & $\mathbf{2}$ & $\mathbf{0 . 2 5}$ & $\mathbf{0 . 2 5}$ & $\mathbf{0}$ \\
\hline Persentase & $\mathbf{7 9 . 2}$ & $\mathbf{1 6 . 7}$ & $\mathbf{2 . 0 8}$ & $\mathbf{2 . 0 8}$ & $\mathbf{0}$ \\
\hline
\end{tabular}

Berdasarkan Tabel 9 memperlihatkan bahwa tidak di temukannya penyuluh yang kinerjanya buruk, persentase terbesar berada pada tingkat sangat baik sebesar 79.2 persen. Hal ini terjadi karena sebagian besar penyuluh membuat data potensi wilayah memandu penyusunan RDKK, penyusunan progama dan membuat rencana kerja tahunan, tetapi masih ada sebagian kecil penyuluh pertanian tidak lengkap dalam penyusunan programa penyuluh.

\section{Pelaksanaan Penyuluh Pertanian}

Pelaksanaan penyuluhan pertanian adalah kegiatan penyuluh dalam melaksanakan kegiatan penyuluhan pertanian yang meliputi Melaksanakan desiminasi/penyebaran, materi penyuluhan sesuai kebutuhan petani, Melaksanakan penerapan metoda penyuluhan pertanian di wilayah binaan, Melakukan peningkatan kapasitas petani, Menumbuhkan dan mengembangkan kelembagaan petani dari aspek, kuantitas dan kualitas, Menumbuhkan dan mengembangkan BUMP dari aspek kuantitas dan kualitas dan Meningkatnya produktivitas. Berdasarkan analisis di lapang tentang kinerja penyuluh pada aspek pelaksanaan pertanian di daerah penelitian secara rinci dapat dilihat dalam Tabel 10 sebagai berikut:

Tabel 10. Dimensi Kinerja Penyuluh Pada Aspek Pelaksanaan Penyuluh Pertanian Di Daerah Penelitian Tahun 2016.

\begin{tabular}{clccccc}
\hline \multirow{2}{*}{ No Indikator } & \multicolumn{5}{c}{ Skor Jarak } \\
\cline { 3 - 7 } & & SB & Ba & C & TB & Bu \\
\hline 1 & Melaksanakan Desiminasi & 3 & 7 & 1 & 1 & 0 \\
2 & Kunjungan/ Tatap Muka & 7 & 4 & 1 & 0 & 0 \\
3 & Demontrasi/SI & 6 & 1 & 5 & 0 & 0 \\
4 & Temu Temu & 7 & 1 & 1 & 0 & 3 \\
5 & Kursus & 6 & 1 & 2 & 0 & 3 \\
6 & Peningkatan Kapasitas Petani & 6 & 2 & 2 & 2 & 0 \\
7 & Menumbuhkan Gapoktan/Kel Tani & 7 & 3 & 1 & 0 & 1 \\
8 & Meningkatkan Kelompok Tani & 8 & 3 & 0 & 0 & 1 \\
9 & Menumbuh dan mengembangkan BUMP & 1 & 2 & 3 & 3 & 3 \\
10 & Meningkatkan Produksi & 8 & 2 & 1 & 1 & 0 \\
\hline Rata-rata & $\mathbf{5 . 9}$ & $\mathbf{2 . 6}$ & $\mathbf{1 . 7}$ & $\mathbf{0 . 7}$ & $\mathbf{1 . 1}$ \\
\hline Persentase & $\mathbf{4 9 . 1 6}$ & $\mathbf{2 1 . 6 7}$ & $\mathbf{1 4 . 1 6}$ & $\mathbf{5 . 8 3}$ & $\mathbf{9 . 1 6}$ \\
\hline
\end{tabular}

Tabel 10. Memperlihatkan bahwa sebagian besar (49.16 persen) penyuluh dalam kegiatan pelaksanaan penyuluhan pertanian berada pada tingkat kinerja dengan kategori sangat baik dan sebagianya lagi tersebar diberbagai aspek kategori.

Kendala yang ditemui di lapangan berdasarkan informasi penyuluh pada aspek pelaksanaan penyuluhan seperti Penyuluh dituntut dalam membaca situasi dan kondisi dimasyarakat tani dalam penyampaikan mansud dan tujuan, penyuluh harus pintar-pintar mencari waktu yang tepat dalam mengumpulkan masyarakat tani guna menyampaikan informasi pertanian. Untuk itu penyuluh biasanya menyampaikan maksud dan tujuanya pada masyarakat tani berkumpul yaitu pada acara hajatan, yasinan dan lain-lain.Menumbuh dan mengembangkan badan usaha milik petani (BUMP) selalu diupayakan oleh penyuluh akan tetapi kendala yang ditemu di lapangan sulitnya bagi penyuluh untuk mendapatkan mitra kerja yang baik, yang dapat menjamin harga produksi. Selain itu antusiasme dari petani dan dari pengurus kurang, petani lebih senang menjual hasil 
produksi ke tengkulak atau toke-toke yang harga produksinya lebih rendah, dikarenakan hutang atau lebih mudah dalam mendapatkan uang.

\section{Evaluasi dan Pelaporan}

Evaluasi dan pelaporan adalah kegiatan penyuluhan dalam melaporkan hasil kegiatan penyuluhan yang telah dilaksanakan meliputi pelaksanaan penyuluhan pertanian dan evaluasi dampak pelaksanaan penyuluhan pertanian. Berdasarkan analisis di lapang tentang kinerja penyuluh pada aspek evaluasi dan pelaporan di daerah penelitian secara rinci dapat dilihat dalam Tabel 11 sebagai berikut;

Tabel 11. Dimensi Kinerja Penyuluh Pada Aspek Evaluasi Dan Pelaporan Penyuluh Pertanian Di Daerah Penelitian Tahun 2016.

\begin{tabular}{|c|c|c|c|c|c|c|}
\hline \multirow{2}{*}{ No } & \multirow{2}{*}{ Indikator } & \multicolumn{5}{|c|}{ Skor Jarak } \\
\hline & & SB & $\mathrm{Ba}$ & C & TB & $\mathrm{Bu}$ \\
\hline 1 & Evaluasi & 6 & 0 & 3 & 1 & 1 \\
\hline 2 & Pelaporan & 9 & 1 & 0 & 1 & 1 \\
\hline \multicolumn{2}{|c|}{ Rata-rata } & 7.5 & 0.5 & 1.5 & 1.5 & 1 \\
\hline \multicolumn{2}{|c|}{ Persentase } & 62.5 & 4.16 & 12.5 & 12.5 & 8.33 \\
\hline
\end{tabular}

Tabel 11. Di atas menunjukan sebagian besar penyuluh (62.5 persen) sudah melakukan evaluasi lebih dari 4 laki dan sudah membuat laporan pelaksanan penyuluhan pertanian di antaranya laporan setiap bulan, tri wulan, semester dan tahun. Dan sebagiannya lagi belum melakukan kegiatan tersebut karna belum lengkap dalam melakukan kegiatan sebelumnya.

\section{Hubungan Antara Kepuasan Kerja Dengan Kinerja Penyuluh}

Berdasarkan uji kolerasi Rank Sperman yang digunakan untuk menguji hubungan antara kepuasan kerja penyuluh dengan kinerja penyuluh di daerah penelitian diperoleh $r s=0,81$ sedangkan nilai tabel $\rho_{s}=0,497$. Karena $r_{s}>$ tabel sehingga keputusan $\mathrm{HO}$ ditolak, artinya terdapat hubungan positif antara kepuasan kerja penyuluh pertanian dengan kinerja penyuluh di daerah penelitian pada tingkat kepercayaan 95\%.

Hal ini menunjukan bahwa di daerah penelitian, kepuasan kerja dapat mendorong penyuluh untuk dapat meningkatkan hasil kerja penyuluh, agar dapat melakukan proses pembelajaran bagi pelaku utama serta pelaku usaha agar mereka mau dan mampu menolong dan mengorganisasikan dirinya dalam mengakses informasi pasar, teknologi, permodalan dan sumberdaya lain, sebagai upaya untuk meningkatkan produktifitas, efisiensi usaha, pendapatan, dan kesejahteraannya, serta meningkatkan kesadaran dalam pelestarian fungsi lingkungan hidup. Hal ini juga sesuai dengan apa yang dituliskan oleh Keith Davis dalam Mankunegara (2005), yang menyatakan bahwa kepuasan bekerja datangnya dari kesukaan atau ketidaksukaan karyawan terhadap pekerjaan yang dilakukannya. Kepuasan merupakan suatu sikap emosional yang dicerminkan oleh moral kerja, kedisplinan dan prestasi kerja. Kepuasan dalam bekerja dan bertindak sebagai penyuluh perindustrian dapat berasal dari pekerjaan, luar pekerjaan dan kombinasi keduanya. Kepuasan yang diperoleh seorang penyuluh dalam penelitian ini diukur berdasarkan beberapa indikator seperti aspek kepuasan terhadap kebutuhan, aspek kepuasan terhadap pengakuan dan aspek kepuas terhadap kondisi kerja. Secara rinci hubungan antara aspekaspek kepuasan kerja dengan kinerja penyuluh adalah sebagai berikut.

\section{Hubungan Antara Aspek Kebutuhan Dengan Kinerja Penyuluh}

Berdasarkan uji kolerasi Rank Sperman yang digunakan untuk menguji hubungan antara kepuasan kerja penyuluh pada aspek kebutuhan dengan kinerja penyuluh di daerah penelitian diperoleh $r s=0,80$ sedangkan nilai tabel $\rho_{s}=0,497$. Karena $r_{s}>$ tabel keputusan $\mathrm{HO}$ ditolak, artinya terdapat hubungan positif antara kepuasan kerja pada aspek kebutuhan penyuluh pertanian dengan kinerja penyuluh di daerah penelitian pada tingkat kepercayaan 95\%.

Seorang penyuluh akan mendapat kepuasan kerja jika ia mempersepsikan bahwa imbalan yang diterima baik berupa gaji, insentif, tunjangan atas pelaksanaan pekerjaan yang dilakukan nilainya lebih tinggi daripada pengorbanannya berupa tenaga dan ongkos yang telah dikeluarkan untuk melakukan pekerjaan itu. Penyuluh pertanian tidak dapat melepaskan diri dari kenyataan bahwa mereka adalah individu yang juga mempunyai kebutuhan dari tempat bekerjanya. Hal ini sejalan dengan teori Asa'ad, (1995), kepuasan kerja adalah suatu 
penilaian dari seseorang mengenai seberapa jauh pekerjaannya secara keseluruhan mampu memuaskan kebutuhannya.

\section{Hubungan Antara Aspek perasaan Dengan Kinerja Penyuluh}

Berdasarkan uji kolerasi Rank Sperman yang digunakan untuk menguji hubungan antara kepuasan kerja penyuluh pada aspek perasaan dengan kinerja penyuluh di daerah penelitian diperoleh $r s=0,73$ sedangkan nilai tabel $\rho_{s}=0,497$. Karena $r_{s}>$ tabel keputusan $\mathrm{HO}$ ditolak, artinya terdapat hubungan positif antara kepuasan kerja pada aspek perasaan dengan kinerja penyuluh di daerah penelitian pada tingkat kepercayaan $95 \%$.

Kepuasan kerja terhadap aspek perasaan penyuluh pertanian tentang pengakuan atas prestasi kerja, penghargaan dan rasa keadilan adalah penilain penyuluh terhadap pekerjaannya. Apabila pengakuan atas prestasi kerja, penghargaan dan rasa keadilan dirasakan sudah sesuai dengan beban pekerjaan akan meningkatkan kinerja penyuluh. kepuasan kerja merupakan perasaan pekerjaan terhadap pekerjaannya (Asa'ad, 1995).

\section{Hubungan Antara Aspek Kondisi Kerja Dengan Kinerja Penyuluh}

Berdasarkan uji kolerasi Rank Sperman yang digunakan untuk menguji hubungan antara kepuasan kerja penyuluh pada aspek kondisi kerja dengan kinerja penyuluh di daerah penelitian diperoleh $\mathrm{rs}=0,71$ sedangkan nilai tabel $\rho_{s}=0,497$. Karena $r_{s}>$ tabel keputusan $\mathrm{HO}$ ditolak, artinya terdapat hubungan positif antara kepuasan kerja pada aspek kondisi kerja penyuluh pertanian dengan kinerja penyuluh di daerah penelitian pada tingkat kepercayaan $95 \%$.

Kondisi kerja seperti waktu kerja, kenyamanan, lingkungan social, dan pendelegasian akan dapat mempengaruhi pada tingkat kepuasan seorang penyuluh pertanian itu sendiri. Suasana serasi di tempat kerja sangat mendukung peningkatan aktivitas kerja yang tinggi dari tenaga kerja sehingga diperoleh keadaan yang memungkinkan tenaga kerja mengembangkan dan meningkatkan kinerjanya untuk mencapai hasil yang sesuai dengan harapan dari organisasi kerjanya (Kusumaatmaja et all, 1991).

\section{KESIMPULAN}

Berdasarkan hasil penelitian yang dilakukan di Kabupaten Tanjung Jabung Barat dapat disimpulkan bahwa,Tingkat kepuasan kerja penyuluh di Kabupaten Tanjung Jabung Barat sebagian besar berada pada kategori sedang, sedangkan Tingkat kinerja penyuluh pertanian di Kabupaten Tanjung Jabung Barat sebagian besar berada pada tingkat cukup dan Hubungan antara kepuasan kerja dengan kinerja penyuluh pertanian di Kabupaten Tanjung Jabung Barat, pada tingkat kepercayaan 95 persen terdapat hubungan yang positif dan signifikan antara kepuasan kerja dengan kinerja penyuluh pertanian yang berarti semakin puas penyuluh terhadap maka semakin baik kinerjanya.

\section{UCAPAN TERIMA KASIH}

Pada kesempatan kali ini penulis menyampaikan ucapan terima kasih kepada Dekan Fakultas Pertanian Universitas Jambi dan Ketua Program Studi Agribisnis Fakultas Pertanian Universitas Jambi yang telah memfasilitasi pelaksanaan penelitian ini, Selain itu ucapan terimakasih juga kepada Ketua kordinator BP3K Kecamatan Batang Asam dan ketua Koordinator BP3K Kecamatan Senyerang yang memfasilitasi pelaksanaan penelitian di lapangan.

\section{DAFTAR PUSTAKA}

As'ad, Moh, 1995. Psikologi Industri : Seri llmu Sumber Daya Manusia,Yogyakarta : Liberty. Hasibuan, Melayu SP, 2008. Manajemen Sumber Daya Manusia, Edisi Revisi : Bumi Aksara Mangkunegara, A.P.2005. Manajemen Sumber Daya Manusia Perusahaan. PT Remaja Rosdakarya. Bandung. Mardikanto, Totok. 1993. Penyuluhan Pembangunan Pertanian. Sebelas Maret Univercity Press. Surakarta. Peraturan Menteri Pertanian .2013. Pedoman Evaluasi Kinerja Penyuluh Pertanian. Jakarta.

Rahmanto. 1997. Membangun Prestasi Kerja Karyawan. www.feunpak.web.id.

Sulistiyani dan Rosidah. 2003. Manajemen Sumberdaya Manusia. Yogyakarta. Penerbit Graha Ilmu.

Siagian, S. P. (2003). Teori dan Praktek Kepemimpinan (cetakan kelima). Jakarta: Rineka Cipta 